\title{
The Role of Chemokines in the Recruitment of Lymphocytes to the Liver
}

\author{
Ye H. Oo Shishir Shetty David H. Adams \\ Centre for Liver Research, Institute of Biomedical Research, University of Birmingham Medical School, and \\ NIHR Biomedical Research Unit for Liver Disease, Queen Elizabeth Hospital, Birmingham, UK
}

\section{Key Words}

Leukocytes $\cdot$ Chemokines $\cdot$ Hepatic inflammation

\begin{abstract}
Chemokines direct leukocyte trafficking and positioning within tissues, thus playing critical roles in regulating immune responses and inflammation. The chemokine system is complex, involving interactions between multiple chemokines and their receptors that operate in combinatorial cascades with adhesion molecules. The involvement of multiple chemokines and chemokine receptors in these processes brings flexibility and specificity to recruitment. The hepatic vascular bed is a unique low-flow environment through which leukocytes are recruited to the liver during homeostatic immune surveillance and in response to infection or injury. The rate of leukocyte recruitment and the nature of cells recruited through the sinusoids in response to inflammatory signals will shape the severity of disease. At one end of the spectrum, fulminant liver failure results from a rapid recruitment of leukocytes that leads to hepatocyte destruction and liver failure; at the other end, diseases such as chronic hepatitis $C$ infection may progress over many years from hepatitis to fibrosis and cirrhosis. Chronic hepatitis is characterized by a T lymphocyte-rich infiltrate and the nature and outcome of hepatitis will depend on the T cell subsets re-
\end{abstract}

\section{KARGER}

(c) 2010 S. Karger AG, Basel

Fax +4161306 1234

E-Mail karger@karger.ch

www.karger.com
Accessible online at:

www.karger.com/ddi cruited, their activation and function within the liver. Different subsets of effector T cells have been described based on their secretion of cytokines and specific functions. These include Th1 and Th2 cells, and more recently Th17 and Th9 cells, which are associated with different types of immune response and which express distinct patterns of chemokine receptors that promote their recruitment under particular conditions. The effector function of these cells is balanced by the recruitment of regulatory $T$ cells that are able to suppress antigen-specific effectors to allow resolution of immune responses and restoration of immune homeostasis. Understanding the signals that are responsible for recruiting different lymphocyte subsets to the liver will elucidate disease pathogenesis and open up new therapeutic approaches to modulate recruitment in favor of resolution rather than injury.

Copyright $\odot 2010$ S. Karger AG, Basel

\section{Chemokines}

Chemokines are 8- to $12-\mathrm{kDa}$ heparin-binding cytokines with the ability to attract leukocyte subsets to specific sites and thereby shape the outcome of immune responses, including intrahepatic inflammation. An efficient immune reaction requires leukocytes to be at the
Prof. David H. Adams, MD, FRCP, FmedSci

5th Floor, Institute of Biomedical Research, University of Birmingham Medical School Wolfson Drive, Edgbaston

Birmingham B15 2TT (UK)

Tel. +44 121415 8702, Fax +44 121415 8701, E-Mail d.h.adams@bham.ac.uk 
right place at the right time, and thus needs a system to regulate the migration and positioning of cells in lymphoid and nonlymphoid tissues [1]. The chemokine system provides cues for the recruitment of effector and regulatory subsets and is central to the pathogenesis of inflammatory diseases.

Chemokines are generally classified into two functional groups, 'inflammatory' and 'homeostatic/constitutive', based on whether they are induced by inflammation or constitutively expressed and involved in homeostatic immune regulation (table 1). Inflammatory chemokines are expressed in inflamed tissues by resident and infiltrating cells on stimulation by pro-inflammatory cytokines or during contact with pathogenic agents. These chemokines are secreted early after infection in response to activation of pattern recognition receptors on epithelial, stromal and immune cells. They recruit the initial wave of innate immune effectors including neutrophils, monocytes, natural killer cells and natural killer T cells, all of which express inflammatory chemokine receptors and immature dendritic cells (DCs) that provide the link between innate and adaptive immunity. After antigen-specific activation of lymphocytes by activated DCs, inflammatory chemokines then attract antigen-specific effector $\mathrm{T}$ cells to the inflammatory site [2]. At the same time, regulatory $\mathrm{T}$ cells are also recruited and the balance between effector and regulatory cells recruitment determines the outcome of the local inflammation.

In contrast, homeostatic chemokines are produced in discrete microenvironments within lymphoid (bone marrow, thymus and secondary lymphoid organs) or nonlymphoid tissues such as the skin and mucosa. These constitutively produced chemokines are involved in physiological trafficking and positioning of cells, antigen sampling in secondary lymphoid tissue and immune surveillance. However, this distinction (although useful) is somewhat artificial because chemokines previously thought to be homeostatic, such as the CCR7 ligands CCL19 and CCL21 and the CXCR5 ligand CXCL13 (which are critical for the development and function of lymphoid tissues), are also induced at sites of chronic inflammation. Homeostatic chemokine receptors bind only one or two chemokines. For example, the chemokine that recruits hematopoietic progenitors to bone marrow has one main receptor CXCR4, and a monogamous pair, CXCR5 and CXCL13, recruit B cells to follicles in lymph nodes; however, receptors that recruit cells to inflammatory sites often have several chemokine ligands [3].

\section{The Human Chemokine System}

The human chemokine system includes more than 50 chemokines and 20 chemokine receptors (table 1) that can be divided into structural subsets based on the presence of $\mathrm{NH}_{2}$-terminal cysteine motifs $[4,5]$. The large CC chemokine family consists of chemokines in which the first two cysteine residues are adjacent, whereas in CXC chemokines, they are separated by a single amino acid residue. Fractalkine (CX3CL1) is the only member of the CX3C chemokine family in which three amino acid residues separate the first two cysteines. Finally, two related chemokines, XCL1 and XCL2, both of which bind the XCR1 receptor, lack two adjacent cysteine residues. Chemokines and their receptors also undergo post-translational modifications which alter their function, allowing them to provide almost limitless potential receptor ligand pairs to bring exquisite specificity to the control of leukocyte homing and positioning in tissues [3].

Dysregulated expression of chemokines and their receptors is involved in the development of many human diseases, including autoimmune and chronic inflammatory diseases as well as immunodeficiency and cancer.

Chemokines exert their chemotactic functions by binding to specific $\mathrm{G}$ protein-coupled receptors, seventransmembrane-spanning proteins coupled to heterotrimeric $\mathrm{G}$ proteins (fig. 1). Chemokine binding to chemokine receptors dissociates $G \alpha_{I}$ and $G \beta-\gamma$ subunits of the heterotrimeric $G$ proteins, leading to calcium flux and activation of the phosphatidylinositol 3-kinase and the small Rho GTPases signaling pathways [6]. Consistent with $G_{i}$ association, the majority of chemokine responses are inhibited by treatment with pertussis toxin [7], which blocks the global $\mathrm{G}$ protein receptor.

\section{Chemokines and Leukocyte Trafficking}

Chemokines regulate leukocyte extravasation into tissue $[3,8,9]$ by providing signals that allow the leukocyte to respond to environmental cues. At least four stages take a free flowing cell from the blood via endothelium into tissue [10]. An initial carbohydrate-dependent 'tether' brings the cell into contact with the vessel wall and a second rolling step slows the leukocyte, allowing interactions with the endothelium. In the liver, rolling is greatly attenuated, probably as a consequence of the low levels of shear stress in hepatic sinusoids, and there is little role for selectins [11, 12]. In the subsequent 'triggering' stage, signaling from the leukocyte chemokine receptor triggers conformational activation of leu- 
Table 1. Chemokines and chemokine receptors in human immune system

\begin{tabular}{|c|c|c|c|}
\hline Receptor & Chemokine & Functions & Distribution of chemokine receptors \\
\hline \multicolumn{4}{|l|}{ CC subgroup } \\
\hline CCR1 & $\begin{array}{l}\text { CCL3, CCL5, CCL7, CCL8, } \\
\text { CCL13-16 }\end{array}$ & $\begin{array}{l}\text { T cell and monocyte migration; hypersenstivity; } \\
\text { innate and adaptive immunity; inflammation }\end{array}$ & monocytes, memory T cells, Th1, NK \\
\hline CCR2 & CCL2, CCL7, CCL8, CCL13 & $\begin{array}{l}\text { T cell and monocyte migration; innate and adaptive } \\
\text { immunity; Th1 inflammation }\end{array}$ & $\begin{array}{l}\text { monocytes, memory T cells, basophils, } \\
\text { pDC }\end{array}$ \\
\hline CCR3 & $\begin{array}{l}\text { CCL5, CCL7; CCL11, } \\
\text { CCL15-16, CCL24, CCL26 }\end{array}$ & $\begin{array}{l}\text { eosinophil and basophil migration; allergic } \\
\text { inflammation; Th2 response }\end{array}$ & eosinophils, basophils \\
\hline CCR4 & CCL17, CCL22 & $\begin{array}{l}\mathrm{T} \text { cell and monocyte migration; allergic inflammation; } \\
\mathrm{T}_{\text {reg }} \text { retention; skin homing; expressed on CD4 Th2 cells }\end{array}$ & $\begin{array}{l}\text { Th2 cells, } T_{\text {reg }} \text { eosinophils, basophils, } \\
\text { DC, } T_{\text {reg }}\end{array}$ \\
\hline CCR5 & CCL3; CCL4; CCL5; CCL8 & $\begin{array}{l}\text { Th1 response, adaptive immunity; inflammation, } \\
\text { HIV infection }\end{array}$ & monocytes, Th1 cells, NK \\
\hline CCR6 & CCL20 & $\begin{array}{l}\text { DC migration, memory T cells, Th17 cells at site of } \\
\text { inflammation }\end{array}$ & $\begin{array}{l}\text { memory T cells, B cells, Th17, } \\
\text { immature mDC }\end{array}$ \\
\hline$\underline{\mathrm{CCR} 7}$ & CCL19, CCL21 & $\begin{array}{l}\text { T cell and DCs homing to secondary lymphoid } \\
\text { tissue; lymphoid development }\end{array}$ & naive $\mathrm{T}, \mathrm{B}$, mature $\mathrm{mDC}$, Th1, Th2, $\mathrm{T}_{\text {reg }}$ \\
\hline CCR8 & CCL1 & T cell trafficking; Th2 response & monocytes, Th2, $\mathrm{T}_{\text {reg }}, \mathrm{NK}$ \\
\hline CCR9 & CCL25 & T cell homing to gut and thymus tolerogenic DCs & DC, memory T cells, thymocytes \\
\hline CCR10 & CCL27, CCL28 & $\mathrm{T}$ cell homing to skin and bowel & memory $\mathrm{T}$ cells, $\mathrm{T}_{\text {reg }}$ \\
\hline
\end{tabular}

\begin{tabular}{llll}
\hline $\begin{array}{l}\text { CXCR1 } \\
\text { CXCR2 }\end{array}$ & CXCL6, CXCL7, CXCL8 & $\begin{array}{l}\text { neutrophil migration; innate immunity; acute } \\
\text { inflammation }\end{array}$ & PMN, monocytes, mast cells \\
\hline CXCR3 & CXCL9, CXCL10, CXCL11 & $\begin{array}{l}\text { T cell recruitment; adaptive immunity; Th1, Th2, } \\
\text { Th17, } \mathrm{T}_{\text {reg }} \text { inflammation }\end{array}$ & PMN, monocytes, mast cells \\
\hline CXCR4 & CXCL12 & stem cell migration; B cell lymphopoiesis $\mathrm{T}$ cells, Th1, Th2, Th17, $\mathrm{T}_{\text {reg, }}$ \\
\hline CXCR5 & CXCL13 & B cell homing in lymphoid organ & T and B cells, monocytes, stem cells, \\
\hline \hline CXCR6 & CXCL16 & T cell migration & NKT \\
\hline CXCR7 & & & B cells \\
\hline
\end{tabular}

CX3C and XC family

$\begin{array}{lll}\text { CX3CR1 CX3CL1 } & \begin{array}{l}\text { T cell and NK cell trafficking and adhesion; innate } \\ \text { and adaptive immunity; Th1 inflammation }\end{array} & \text { monocytes, Th1, NK }\end{array}$

\begin{tabular}{llll}
\hline XCR1 XCL1-2 NK cell recruitment & NK
\end{tabular}

Chemokine receptors can be divided into subfamilies on the basis of the position of conserved cysteine residues within a conserved tetracysteine motif. In CC chemokines, the first two consensus cysteines are next to each other; in CXC chemokines, they are separated by a nonconserved amino acid. These two subfamilies account for all but three of the known chemokines, the others being CX3CL1 (three intervening amino acids between the first cysteines) and XCL1 and XCL2, which lack two of four canonical cysteines. Data have been drawn from Viola and Luster [89], and Heydtmann and Adams [120]. Human chemokines and chemokine receptors could also be classified according to their function: inflammatory (italics) and homeostatic (underlined). Chemokines and their receptors belonging to both subfamilies are shown in bold. $\mathrm{CCL}=\mathrm{Chemokine}(\mathrm{C}-\mathrm{C}$ motif) ligand; $\mathrm{CCR}=$ chemokine $(\mathrm{C}-\mathrm{C}$ motif $)$ receptor; $\mathrm{CXCL}=$ chemokine (C-X-C motif) ligand; $\mathrm{CXCR}=$ chemokine (C-X-C motif) receptor; $\mathrm{CX} 3 \mathrm{CL}=$ chemokine $(\mathrm{C}-\mathrm{X} 3-\mathrm{C}$ motif) ligand; $\mathrm{CX} 3 \mathrm{CR}=$ chemokine (C-X3-C motif) receptor; $\mathrm{mDC}=$ myeloid dendritic cell; $\mathrm{NK}=$ natural killer; $\mathrm{NKT}=$ natural killer $\mathrm{T} ; \mathrm{pDC}=$ plasmacytoid dendritic cell; $\mathrm{PMN}=$ polymorphs; Th1 $=\mathrm{T}$ helper 1 ; Th2 $=\mathrm{T}$ helper 2 ; Th17 $=\mathrm{T}$ helper $17 ; \mathrm{T}_{\text {reg }}=$ regulatory $\mathrm{T}$ cell. 
Fig. 1. Schematic diagram of the G protein-coupled receptor. Chemokine receptors are seven-transmembrane molecules coupled to heterotrimeric G proteins. When the chemokine interacts with its receptor, the $\beta$ - and $\gamma$-subunits are assembled into $\beta \gamma$-dimers that act as functional units. The $\alpha$-subunits bind guanine nucleotides, and are active when GTP is bound. The $G$ proteins are usually classified into four classes, $\alpha_{i}, \alpha_{s}, \alpha_{q}$ and $\alpha_{12 / 13}$, by the nature of their $\alpha$-subunit. Chemokine receptors can signal through different $\mathrm{G} \alpha$-protein families, leading to distinct transduction pathways and downstream biological effects. Adapted from Viola and Luster [89].

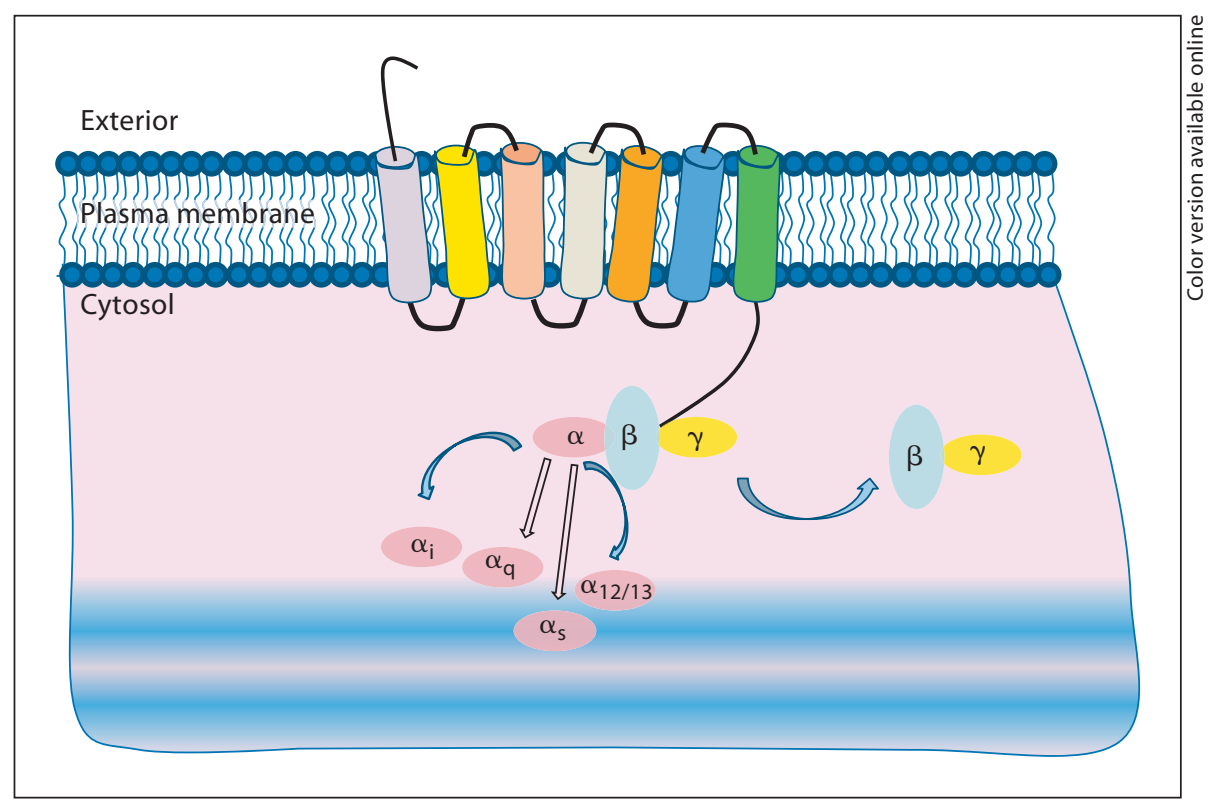

kocyte integrins that mediate firm adhesion to endothelial ligands, such as ICAM-1 and VCAM-1. This stage includes slow rolling, arrest, adhesion strengthening and intravascular crawling, in which the leukocyte migrates on the vessel wall looking for the signals that drive transmigration through endothelium into tissue. Arrest depends on rapid increases in integrin affinity in response to chemokines displayed on proteoglycans on the endothelial glycocalyx [13].

During diapedesis, leukocytes migrate across the endothelium and basement membrane to enter tissue [10, 14]. In most tissues, diapedesis is regulated by adhesion receptors that localize to endothelial junctions through which the majority of migrating leukocytes cross. However, hepatic sinusoids lack conventional tight junctions, and the signals required for transmigration may differ in the sinusoids [15]. Additionally, how cells traverse the space of Disse is poorly understood. Once in tissue, the leukocyte follows chemokine gradients to sites of injury or infection. In secondary lymphoid tissues leukocytes can migrate through tissues in the absence of integrins by using chemokine-mediated changes in the actin cytoskeleton to propel migration $[16,17]$.

Chemokines secreted by other cells in the microenvironment can be taken up and undergo transcytosis across endothelial cells for presentation on the endothelial glycocalyx, thereby localizing chemokines to specific sites in the vasculature [18] where they can undergo further posttranslational activation or deactivation by ectoenzymes such as CD26 [3, 19]. A group of promiscuous nonsignal- ing chemokine receptors, termed interceptors, act as a sump to remove chemokines, or in the case of D6, promote their disposal via lymphatics [20]. One such receptor, DARC, promotes chemokine transcytosis and retention when expressed on endothelium; however, on red cells it retains chemokines in the circulation, thereby preventing random activation of circulating leukocytes [21].

\section{Hepatic Inflammation and Chemokines}

The liver has an important role in the removal of pathogens and particulate antigens entering from the systemic circulation via the hepatic artery and from the gut via the portal vein. Blood enters the hepatic parenchyma via sinusoids, which are low-flow vascular channels that are supplied by both the hepatic artery and portal veins and lined by specialized liver sinusoidal endothelial cells, which are interspersed with the liver-resident macrophage population of Kupffer cells (KCs). The sinusoids drain into the central veins and from there blood returns to the systemic circulation. Liver sinusoidal endothelial cells have open fenestrae arranged in sieve plates which allow the passage of solutes between blood and underlying cells and which also allow contact between hepatocytes and leukocytes within the sinusoids. The space of Disse lies beneath the endothelium and contains hepatic stellate cells and DCs (fig. 2, 4). The liver is constantly exposed to food antigens and low levels of endotoxin from the gut and has evolved mecha- 


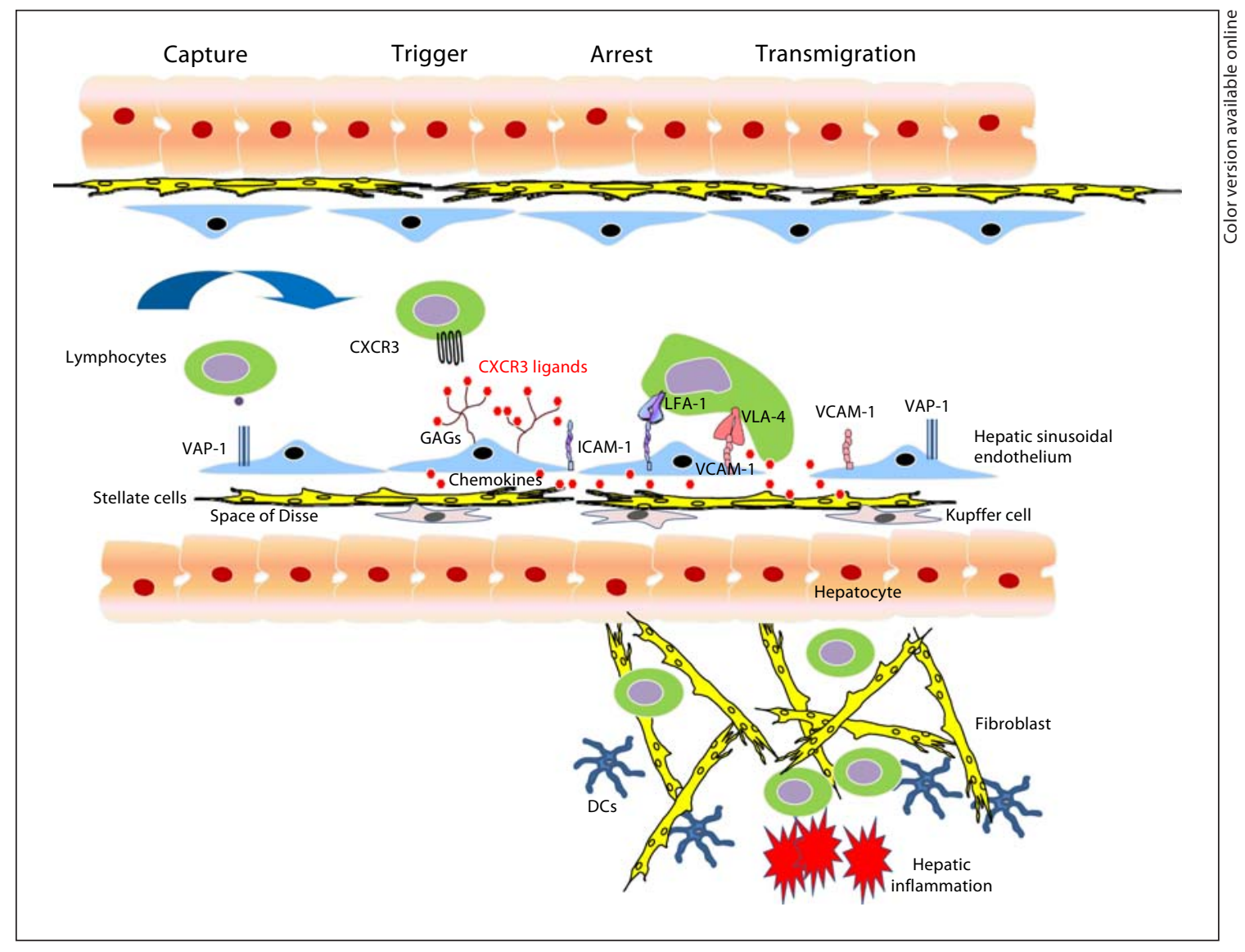

Fig. 2. Leukocyte adhesion cascades in hepatic sinusoid. Chemokines are critical factors in regulating lymphocyte recruitment from the blood into the liver. Leukocyte extravasation into tissue involves multiple steps. First, lymphocytes are captured, bringing the flowing cell into contact with the vessel wall, to interact with the endothelium. Second, triggering involves chemokines which are immobilized on the endothelial glycocalyx that activate chemokine receptors on leukocytes, resulting in integrin binding to endothelial ligands such as ICAM-1 and VCAM-1. During this

nisms to suppress immune responses to harmless antigens whilst maintaining the capacity to respond to infections, such as hepatitis viruses [22, 23]. In chronic inflammatory and autoimmune liver diseases, such responses are generated and persist, leading to chronic hepatitis, fibrogenesis and eventually cirrhosis. Vigorous intrahepatic immune responses probably depend on activation of Tlymphocytes by mature, fully activated DCs within secondary lymphoid tissues (fig. 4). Whether the final result of immune recognition is immune tolerance or an effector response, the initial step is the recruitment of lymphocytes from blood via interactions with liver sinusoidal endothelial cells (fig. 4). stage, the leukocyte adheres on the vessel wall. Finally transendothelial migration into tissue occurs, which involves chemokines. Once in tissue, the cell follows chemokine gradients to sites of inflammation, using chemokine-mediated changes in the actin cytoskeleton to propel migration. $\mathrm{CXCR}=$ Chemokine $(\mathrm{C}-\mathrm{X}-\mathrm{C}$ motif) receptor; ICAM-1 = intercellular cell adhesion molecule 1; VCAM-1 = vascular cell adhesion molecule 1; VAP-1 = vascular adhesion protein-1; CXCR3 ligands = MIG, IP-10, I-TAC.

\section{Lymphocytes: Regulators vs. Effectors}

In chronic hepatitis, both effector subsets and regulatory lymphocytes are found at the site of inflammation, and the balance of the cells recruited will determine the nature of the hepatitis and liver disease [24]. The naive CD4 $\mathrm{T}$ cell is a multipotential precursor with defined antigen specificity, but substantial plasticity, for development down distinct effector or regulatory lineages, contingent upon signals from cells of the innate immune system. The most important lineages are Th1, Th2, Th17 and Th9 effector cells and anti-inflammatory regulatory $\mathrm{T}$ cells ( $\mathrm{T}_{\text {reg; }}$ fig. 3 ). Th1 cells differentiate in response to

Dig Dis 2010;28:31-44 


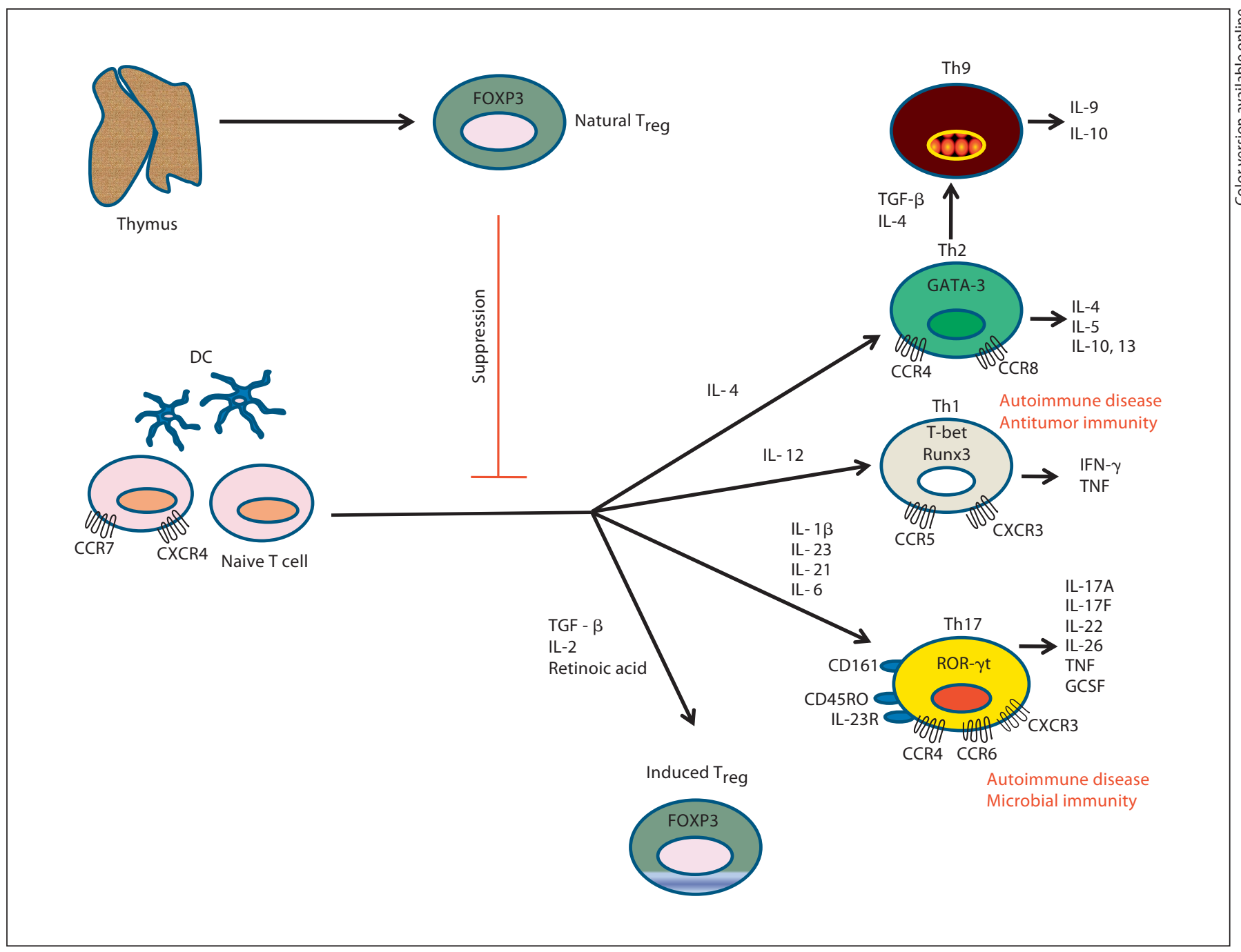

Fig. 3. $\mathrm{T}$ cell lineage and balance between $\mathrm{T}_{\text {reg }}$ and $\mathrm{Th} 1, \mathrm{Th} 2, \mathrm{Th} 17$ and Th9. Cytokine-mediated amplification of effector CD4+ Th1, Th2, Th17 and Th9 cells. After being activated, naive T cells differentiate into distinct CD4+ helper T cell subsets depending on the cytokine milieu, which drives a program of differentiation that includes the induction of key transcription factors as well as specific chemokine receptors. Th1 cells express inflammatory type chemokine receptors CCR5 and CXCR3, Th2 cells express CCR4 and CCR8, and the recently discovered Th17 cells express CCR4, CCR6 and CXCR3. Th9 subsets were demonstrated recently from Th2 cells lineage when they were stimulated by IL- 4 and TGF- $\beta$. Naturally occurring, thymic-derived $\mathrm{T}_{\text {reg }}$ maintain the immune tolerance and prevent excessive damage during infection and inflammation by controlling these $\mathrm{T}$ effector cells. interleukin (IL)-12 via signaling through signal transduction and activator of transcription (STAT) 4 and the transcription factor T-bet. Interferon (IFN)- $\gamma$, tumor necrosis factor (TNF)- $\alpha$ and lymphotoxin are involved in cell-mediated immunity and the clearance of intracellular pathogens including viruses. The differentiation of Th2 cells is driven by IL-4, STAT- 6 and Gata-3. They secrete IL-4, IL-5, IL-10, IL-13 and IL-21 and are involved in humoral immunity and the clearance of ex- tracellular organisms and parasites. The recently described IL-17 secreting CD4 T cells mediate defense against extracellular bacteria and fungi and drive inflammatory and autoimmune disease $[25,26]$. Th17 differentiation is programmed during $\mathrm{T}$ cell activation in the presence of IL-6, transforming growth factor (TGF)$\beta$, IL-1 $\beta$ and IL-21 [125-128], leading to expression of the transcription factor ROR- $\gamma t$ via activation of STAT-3 and the aryl hydrocarbon receptor (AHR) $[27,28]$. Their 


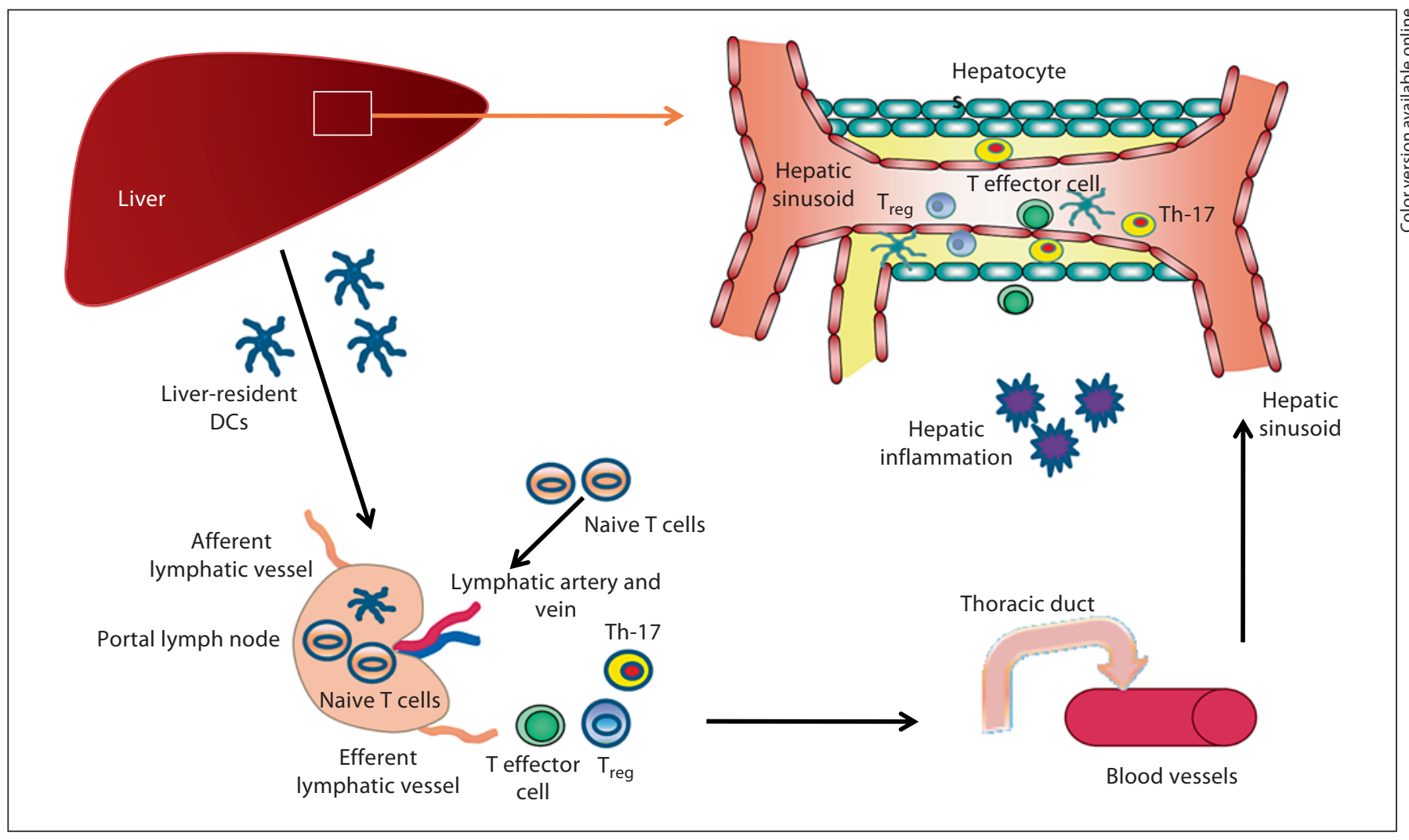

Fig. 4. Regulatory and effector $T$ cell recruitment to hepatic inflammation. During hepatic inflammation, liver-resident DCs sample foreign antigen and carry it to local portal lymph nodes for presentation to naive $T$ cells recruited via high endothelial venules of lymph nodes. Following antigen presentation, different types of $\mathrm{T}$ effector and $\mathrm{T}$ regulatory cells leave the nodes and drain back to systemic circulation before being recruited into the liver and the site of injury or inflammation via low-flow hepatic sinusoidal endothelial vascular bed. Local antigen presentation by epithelial and endothelial cells to naive T cells in the liver usually results in immunological tolerance, although microenvironmental signals form cytokines, and APCs are be important in maintaining inflammation and a polarized local immune response [121-123]. expansion and pathogenicity is maintained by IL-23 [29, 30]. Th17 cells secrete IL-17A, IL-17F and CCL20, and depending on local signals IL-22, IFN- $\gamma$ or IL-10. They express high levels of CCR6 and CCR4, but little is known about the signals responsible for their recruitment to inflamed tissues [31].

Several observations implicate Th17 cells in inflammatory liver disease [32-36]:

- Hepatic IL-17 is increased in autoimmune/inflammatory diseases and the IL-6-, TGF- $\beta$-rich hepatic environment contributes to IL-17 induction [32].

- IL-22, a signature Th17 cytokine, is increased in liver disease and induces hepatocyte proliferation $[35,37]$.

- Endogenous ligands for the aryl hydrocarbon receptor $[38,39]$ include bilirubin which has an $\mathrm{EC}_{50}$ for aryl hydrocarbon receptor activation of $30 \mu \mathrm{M}$, a level seen in clinical jaundice [40].
- Increased numbers of IL-17+ cells are found in human liver disease. We detected IL17+ CD4 (Th17) and CD8 (Tc17) cells in liver from patients with autoimmune liver disease or steatohepatitis and in collaboration with Paul Klenerman (Oxford) showed that intrahepatic Tc17 cells predict outcome in chronic hepatitis C [129]. Th17 and Tc17 cells from the liver express CD161 [41], IL-23R and RORc and high levels of CCR5, CCR6, CXCR3 and CXCR6. They include subpopulations that secrete IL-22 and IFN- $\gamma$ [35]. Th17 cells are associated with many types of hepatitis, but may be particularly important in steatohepatitis where they are associated with a neutrophil-rich lymphocytic infiltrate and extensive tissue destruction.

- Hepatic endothelium and epithelium express IL-17 receptors and respond to IL-17 by secreting chemokines (fig. 2) [35]. 
It has recently been shown that another subset of Th9 cells that secrete IL-9 can develop from Th2 cells stimulated with IL- 4 and TGF- $\beta$. On the regulatory arm of the immune system, $\mathrm{CD} 4+\mathrm{T}_{\text {reg }}$ develop in response to retinoic acid and TGF- $\beta$ and activation of STAT- 5 and the transcription factor FOXP3 [124]. $\mathrm{T}_{\text {reg }}$ suppress immune response against self-antigens and also damp down effector responses to allow resolution and the restoration of immune homeostasis, thereby preventing autoimmunity and uncontrolled inflammation and tissue injury.

A critical factor in regulating the involvement of specific subsets at sites of inflammation is the differential expression of chemokine receptors between these different subsets of $\mathrm{T}$ cells. In human blood, effector CD8 T cells express CXCR3, CCR5 and CXCR6 as do Th1 cells, whereas Th2 cells express CCR4 and CCR8, Th17 cells express CCR4, CCR6, CXCR3 and CXCR6 [31, 42-45] (fig. 3 ) and $\mathrm{T}_{\text {reg }}$ express CCR4 and CXCR3 [130]. Thus the combination of $\mathrm{T}$ cells recruited will be shaped by the expression of local chemokines that can attract specific subsets of cells $[46,47]$.

\section{Roles of Chemokines in the Context of Hepatic Inflammation}

Immune surveillance in the liver is provided by both resident and blood-borne lymphocytes and macrophages [48]. During liver inflammation, the rate of lymphocyte recruitment via sinusoidal endothelium increases and retention within the liver by localization at sites of inflammation or at epithelial surfaces results in chronic hepatitis and persistent inflammation [49]. Chronic hepatitis C virus (HCV) infection and primary biliary cirrhosis are both dominated by Th1 immune responses [50-52], whereas there is some evidence for Th2 involvement in primary sclerosing cholangitis (PSC). Recent studies suggest that alcoholic and non-alcoholic steatohepatitis (from our own unpublished data) involve Th-17 responses which may explain the characteristic neutrophil-rich infiltrate [33]. However, unlike some murine models, human chronic inflammatory diseases cannot be so easily assigned to Th1- versus Th2- versus Th17-dominated responses and it is likely that overlapping mechanisms are involved in most situations. Most effector T cells infiltrating the chronically inflamed human liver express high levels of CXCR3, CXCR6, CCR1 and CCR5 consistent with a Th1 predominance and a tissue-infiltrating phenotype $[51,53-56]$; the roles played by these different receptors in recruitment is beginning to be understood. In addition to
Table 2. Chemokines and receptors involved in the pathogenesis of liver disease

\begin{tabular}{lll}
\hline Location in the liver & Chemokines & $\begin{array}{l}\text { Chemokine } \\
\text { receptor }\end{array}$ \\
\hline $\begin{array}{l}\text { Portal vessels } \\
\text { Liver sinusoids }\end{array}$ & CCL3, 4, 5 & CCR5 \\
CXCL9, 10, 11 & CXCR3 \\
Biliary epithelium & CXCL16 & CXCR6 \\
& CCL28 & CCR10 \\
& CXCL16 & CXCR6 \\
CX3CL1 & CX3CR1 \\
$\begin{array}{l}\text { Portal-associated } \\
\text { lymphoid tissue }\end{array}$ & CXCR4 & CXCL12 \\
\hline
\end{tabular}

Lymphocytes can be recruited across the portal endothelium, which is mediated by the chemokines CCL3-5, ligands for CCR5. Recruitment across liver sinusoidal endothelium is mediated by the chemokines CXCL9-11 as well as CXCL16. CCL28 expression on biliary epithelial cells has been associated with the recruitment of CCR10 expressing regulatory T cells. In some forms of chronic hepatic inflammation, there is neovessel formation within the portal tracts which has characteristics of lymphoid tissue, which is termed portal-associated lymphoid tissue and has been shown to be associated with the chemokines CCL19 and CCL21, which are ligands for CCR7.

recruiting different subsets of lymphocytes, there is evidence for compartmentalization of recruitment as well. CCR5 may have a particular role in recruitment to portal tracts, whereas CXCR3 appears to be essential for recruitment into the parenchyma (table 2) [57-60].

CXCR3 and Its Ligands CXCL9, CXCL10 and CXCL11 in Lymphocyte Recruitment

Expression of CXCR 3 on T cells is closely linked to Th1 function, and its ligands CXCL9, CXCL10 and CXCL11 are induced by the Th1 cytokines IFN- $\gamma$ and TNF- $\alpha$. Studies dating back 10 years report increased levels of CXCR3 ligands in chronic hepatitis and of increased CXCR3 on CD4 and CD8 effector cells within the liver [61-65]. Increased levels of hepatic CXCR3 ligands are characteristic of many chronic inflammatory liver diseases, suggesting they play a generic role in effector cell recruitment to the inflamed liver $[60,66,67]$. The sources of CXCR3 ligands in liver inflammation include hepatocytes, stellate cells, sinusoidal endothelial cells and infiltrating leukocytes. The expression of CXCR3 ligands requires stimulation with IFN- $\gamma$ and TNF- $\alpha$, which are released by activated hepatic macrophages, KCs and the initial wave of infiltrating innate immune cells $[59,61,68]$. An additional contri- 
bution comes from activated CD4+ T cells themselves, which release CXCR3 ligands after activation within the liver [69], thereby providing a feedback loop in which antigen-specific cells maintain the expression of the chemokines required for effector cell recruitment.

Our group has previously demonstrated by using flowbased adhesion assays that chemokines CXCL9, CXCL10 and CXCL11 are important not only in adhesion, but also in transmigration of effectors $\mathrm{T}$ lymphocytes through hepatic endothelium under physiological conditions of blood flow [60, 70]. CXCR3 ligands on the sinusoidal wall can originate from neighboring cells and then be taken up and transcytosed to the endothelial surface [71]. In addition, chemokines secreted 'upstream' by other cell types including cholangiocytes in portal tracts can be captured from the slow-flowing sinusoidal blood by proteoglycans within the endothelial cell glycocalyx and presented at the endothelial surface [60]. Thus, local presentation of chemokines on the sinusoids is the result of cross-talk between sinusoidal endothelial cells and stellate cells, KCs, cholangiocytes and hepatocytes, all of which secrete chemokines upon appropriate stimulation [72-74]. Hepatocytes not only secrete chemokines, but also sensitize the endothelium to respond to low levels of TNF- $\alpha$ by increasing chemokine secretion and adhesion molecule expression $[24,75]$.

In chronic hepatitis, many of the infiltrating cells are probably not antigen-specific, but rather bystander lymphocytes recruited as part of a broad immune response. Both antigen-dependent and independent infiltrating effector cells express high levels of CD154, whose ligand, CD40, is expressed on hepatocytes, cholangiocytes and KCs. Activation of CD40 on these liver cells triggers $\mathrm{NF \kappa B}$-dependent secretion of CXCR3 ligands [76, 77], demonstrating another mechanism by which local chemokine gradients can be amplified during the evolution of the anti-viral immune response. The situation is further complicated by the recent evidence that $\mathrm{T}_{\text {reg }}$ also use CXCR3 to enter liver tissue, although other signals may determine where they migrate to within the inflamed liver and, hence, where they mediate their anti-inflammatory effects [78].

\section{CXCR6, CXCL16 and Immune Cell Localization at}

Epithelial Surfaces in the Liver

In human blood, CXCR6 is expressed on Th1 cells and effector CD8 T cells. We and others have reported high levels of CXCR6 on CD4 and CD8 T cells within the inflamed human liver. The CXCR6 ligand CXCL16 is one of only two chemokines that exist in a transmembrane form [79-81]. CXCL16 is upregulated on inflamed bile ducts and hepatocytes and is also expressed by sinusoidal endothelium. The engagement of CXCR6 on T cells by CXCL16 on epithelial cells promotes $\beta 1$ integrin-dependent adhesion, which we believe is important for the positioning, retention and survival of effector cells in the inflamed liver [82]. Klenerman and colleagues [41] have recently reported a unique subset of $\mathrm{HCV}$-specific CXCR6+ liver-infiltrating CD8 T cells which express the C-type lectin CD161 and secrete IL-17 and IFN- $\gamma$. Defining these cells may represent an important liver-specific subsets of effector cells.

Other chemokines may also be involved in retaining $\mathrm{T}$ cells within the liver. These include CXCL12 $[83,84]$ and the other transmembrane chemokine CX3CL1 (fractalkine), both of which are expressed on inflamed bile ducts $[85,86]$. The fractalkine receptor CX3CR1 is expressed by Th1 cells and may help to retain these cells at sites of epithelial inflammation. We detected increased expression of another chemokine, CCL28, on cholangiocytes in a variety of liver diseases, including HCV, and found increased numbers of T cells expressing the CCL28 receptor, CCR10, in the inflamed human liver [78]. A high proportion of these cells were $\mathrm{FOXP}^{+} \mathrm{CD} 4$ cells that secrete IL-10 and suppress $\mathrm{T}$ cell activation. Thus, $\mathrm{CCl} 28$ appears to recruit regulatory rather than effector cells to bile ducts. When compared with $\mathrm{T}_{\text {reg }}$ in blood the CCR10+, liver-derived $\mathrm{T}_{\text {reg }}$ express high levels of CXCR3 and low levels of CCR7 consistent with a tissue-infiltrating phenotype leading us to propose that they use CXCR3 to enter the liver but then localize to inflamed bile ducts using CCR10. CCL28 was originally isolated from the gut, but is widely expressed at mucosal surfaces throughout the body $[87,88]$.

\section{CCR5 and CCR1/CCL5 and Liver Inflammation}

CCR1, CCR2 and CCR5 have all been implicated in hepatic inflammation. CCR 2 and CCR 5 expressing CD8 $\mathrm{T}$ cells are enriched in the inflamed human liver, and CCR1 is important in the regulation of hepatic inflammation in murine models $[51,55]$. The three receptors share chemokine ligands: CCR5 interacts with CCL3, CCL4, CCL5 and CCL8; CCR2 with CCL2, CCL13, CCL7 and CCL8; and CCR1 with CCL3, CCL5, CCL7, CCL23 and CCL14-16 [3, 89]. All of these chemokines have been detected in the liver [51, 56, 90-92]. CCR1, CCR2 and CCR5 expression is characteristic of memory T cells and CCR5 is expressed on Th1 cells $[89,93]$, with particularly high frequencies detected in the human liver $[51,55,90]$. CCR5 ligands are strongly expressed on portal and vascular en- 
dothelium [94] and in murine models of graft-versus-host disease CCR5 and CCL3 support effector cell recruitment to portal tracts $[57,95]$. Although other murine models of liver inflammation are characterized by intrahepatic CCR5+ lymphocytes [96, 97], mice that lack CCR5 are more susceptible to Con A-induced hepatitis and exhibit extensive inflammation mediated by CCR $1+$ effectors [ 58 , 97]. This emphasizes the complexity of chemokine networks and suggests that under some conditions CCR5 recruits anti-inflammatory as well as effector cells [96].

\section{Homeostatic Chemokines and Lymphocyte Egress} from the Liver

Homeostatic chemokines can be upregulated at sites of inflammation where they play important roles in regulating leukocyte trafficking, particularly through the formation of tertiary neolymphoid structures $[98,99]$. Neolymphoid follicles that express CCL19 and CCL21 are a feature of many chronic inflammatory liver diseases, particularly PBC, PSC and HCV infection [54]. They may be sites for ongoing lymphocyte recruitment and provide survival signals to maintain the chronic inflammatory infiltrate within the liver $[83,84,100,101]$. The CCR7 receptor is expressed by naive $\mathrm{T}$ cells and a subset of central memory cells to promote their recirculation through secondary lymphoid tissues. However, we detected CCR7+ $\mathrm{T}$ cells in livers from patients with chronic autoimmune liver disease and chronic HCV infection [100]. However, most (if not all) of these cells were memory rather than naive cells [54, 102], thus CCR7+ CD8 T cells in the $\mathrm{HCV}$-infected liver were CD62 $\mathrm{L}^{\text {low }}$ and LFA-1 ${ }^{\text {high }}$, which is characteristic of memory cells. Because CCL19 and CCL21 are expressed on sinusoids and lymphatic vessels in portal tracts $[54,98]$, we suggest that these cells use CCR7 to migrate out of the liver via afferent lymphatics to drain lymph nodes where they are either removed during the resolution of infection or re-stimulated to maintain chronic hepatitis. This pathway may be defective in $\mathrm{HCV}$ infection because the numbers of intrahepatic CCR7+ memory T cells are reduced. Others groups have reported an important role for CCR7 in promoting resolution of inflammation, and a lack of CCR7 in mice leads to enhanced inflammation [103-105].

\section{CCR9 and the Gut-Liver Interface in PSC}

PSC, a chronic inflammatory liver disease characterized by progressive bile duct destruction, develops as an extra-intestinal complication of inflammatory bowel dis- ease. The existence of a population of long-lived memory $\mathrm{T}$ cells capable of homing both to the liver and the gut could explain the link between inflammatory bowel disease and liver disease. Evidence suggests that a proportion of the lymphocytic infiltrate in PSC consists of cells generated in the gut during episodes of inflammation which enter the liver in response to aberrantly expressed gut-homing molecules and chemokines [46]. The gut-associated chemokine CCL25 regulates the recruitment of T cells to the bowel by $[46,106,107]$ activating its receptor CCR9, which is largely restricted to mucosal T cells and which promotes adhesion of $\alpha_{4} \beta_{7}+$ to MAdCAM-1 expressed on gut vessels [108]. We have found that in PSC, $20 \%$ of effector T cells in the liver express CCR 9 and $\alpha 4 \beta 7$ and that the hepatic endothelium expresses CCL25 and MADCAM-1, providing a mechanism to explain the recruitment of $\alpha_{4} \beta_{7}+$ CCR $9+$ mucosal lymphocytes to the liver [70]. The unique CCR $9+/ \alpha_{4} \beta_{7}+$ phenotype is imprinted on T cells during activation by gut DCs $[109,110]$, but we have been unable to reproduce this phenotype using liver-derived DCs, suggesting that the cells must originally have been activated in the gut [111]. The liver-infiltrating CCR $9+\alpha_{4} \beta_{7}$ cells are primed to secrete IFN- $\gamma$ on stimulation, suggesting that they can be rapidly expanded into effector cells in the liver, thereby mediating inflammatory damage, although the triggering antigen is still unknown.

\section{Regulatory T Cells, Chemokines and Human Liver}

Expression of distinct chemokine receptors by $\mathrm{T}_{\text {reg }}$ is critical for their recruitment and localization in inflamed nonlymphoid sites for the suppression of effector $\mathrm{T}$ cell-mediated inflammatory responses. The chemokine receptors expressed by $\mathrm{T}_{\text {reg }}$ will depend upon the cytokine milieu in which they are activated. Inducible $\mathrm{T}_{\text {reg }}$ can express patterns of homing receptors that overlap with T effector cells, Th1 cells (CXCR3, CCR5 and CXCR6), Th2 cells (CCR4 and CCR8) and Th17 cells (CCR4, CCR6, CCR2 and CXCR3), allowing $\mathrm{T}_{\text {reg }}$ to colocalize together with diverse effector $\mathrm{T}$ cells to suppress a wide range of inflammatory conditions [112]. We have found that $\mathrm{T}_{\text {reg }}$ in the inflamed human liver express CXCR3 and use this receptors to migrate through sinusoidal endothelium under flow, whereas they co-localise within the liver using different receptors: CCR10 for recruitment to biliary epithelium and CCR4 to co-localise with liver infiltrating dendritic cells within inflammatory infiltrates $[78,130]$. 


\section{Interstitial Migration and Position of Recruited Lymphocytes}

Once they have crossed the endothelial barrier, infiltrating lymphocytes need cues to position themselves in tissue and chemokines can provide such coordinated directed migration signals [113], particularly when acting as a surface-bound gradient in the extracellular matrix and stromal cells $[114,115]$. The stroma can also modulate the function of the overlying endothelium, emphasizing the importance of the tissue microenvironment in shaping recruitment [116]. Leukocyte migration within interstitial tissue in vitro and in vivo is only partially integrin-dependent, being directed instead by chemokinedependent migration along the confining ECM scaffold. In the setting of hepatic inflammation, once the lymphocytes are recruited into the inflamed tissue, the liver stromal cell network, characterized by hepatic stellate cells and activated liver myofibroblasts, direct the post-endothelial migration (fig. 2) [117, 118]. This is partly chemokine-dependent, but also involves chemokine-independent mechanisms [119].

\section{Conclusions}

Chemokines are a family of structurally related proteins that share the ability to induce migration of specific subsets of leukocytes, both effectors and regulators and are critical regulators of immunity and inflammation in human liver diseases. These specialized chemotactic cytokines play a central role in the generation of cellular inflammation, both in the protective responses to invading pathogens and in the pathological processes associated with infection and immune-mediated diseases. Understanding the role of specific chemokines might allow them to be targeted for therapeutic intervention in a wide range of diseases. However, such approaches are complex because although blocking chemokines that drive inflammation and fibrogenesis may be beneficial, such approaches run the risk of inhibiting the anti-inflammatory regulatory immune response.

\section{Disclosure Statement}

Y.H.O. is funded by National Institute of Health Research and Medical Research Council; S.S. is funded by a Core Fellowship.

\section{References}

1 von Andrian UH, Mackay CR: T-cell function and migration. Two sides of the same coin. N Engl J Med 2000;343:1020-1034.

$\checkmark 2$ Heydtmann M, Adams DH: Understanding selective trafficking of lymphocyte subsets. Gut 2002;50:150-152.

$\checkmark 3$ Rot A, von Andrian UH: Chemokines in innate and adaptive host defense: basic chemokinese grammar for immune cells. Annu Rev Immunol 2004;22:891-928.

$\checkmark 4$ Zlotnik A, Yoshie O: Chemokines: a new classification system and their role in immunity. Immunity 2000;12:121-127.

$\checkmark 5$ Moser B, Loetscher P: Lymphocyte traffic control by chemokines. Nat Immunol 2001; 2:123-128.

6 Mellado M, Rodriguez-Frade JM, Mañes S, Mart/nez-A C: Chemokine signaling and functional responses: the role of receptor dimerization and TK pathway activation. Annu Rev Immunol 2001;19:397-421.

$\checkmark 7$ Goldman DW, Chang FH, Gifford LA, Goetzl EJ, Bourne HR: Pertussis toxin inhibition of chemotactic factor-induced calcium mobilization and function in human polymorphonuclear leukocytes. J Exp Med 1985;162:145-156.
8 Ebert LM, Schaerli P, Moser B: Chemokinemediated control of $\mathrm{T}$ cell traffic in lymphoid and peripheral tissues. Mol Immunol 2005; 42:799-809.

$\checkmark 9$ Schreiber TH, Shinder V, Cain DW, Alon R Sackstein R: Shear flow-dependent integration of apical and subendothelial chemokines in T-cell transmigration: implications for locomotion and the multistep paradigm. Blood 2007;109:1381-1386.

$>10$ Ley K, Laudanna C, Cybulsky MI, Nourshargh S: Getting to the site of inflammation: the leukocyte adhesion cascade updated. Nat Rev Immunol 2007;7:678-689.

11 Wong J, Johnston B, Lee SS, et al: A minimal role for selectins in the recruitment of leukocytes into the inflamed liver microvasculature. J Clin Invest 1997;99:2782-2790.

12 Adams DH, Hubscher SG, Fisher NC, Williams A, Robinson M: Expression of E-selectin and E-selectin ligands in human liver inflammation. Hepatology 1996;24:533-538.

13 Tanaka Y, Adams DH, Hubscher S, Hirano H, Siebenlist U, Shaw S: T-cell adhesion induced by proteoglycan-immobilized cytokine MIP-1 beta. Nature 1993;361:79-82.
${ }_{14}$ Yadav R, Larbi KY, Young RE, Nourshargh S: Migration of leukocytes through the vessel wall and beyond. Thromb Haemost 2003;90: 598-606.

15 Lee WY, Kubes P: Leukocyte adhesion in the liver: distinct adhesion paradigm from other organs. J Hepatol 2008;48:504-512.

16 Woolf E, Grigorova I, Sagiv A, et al: Lymph node chemokines promote sustained T lymphocyte motility without triggering stable integrin adhesiveness in the absence of shear forces. Nat Immunol 2007;8:1076-1085.

17 Lammermann T, Bader BL, Monkley SJ, et al: Rapid leukocyte migration by integrin-independent flowing and squeezing. Nature 2008;453:51-55.

18 Middleton J, Neil S, Wintle J, et al: Transcytosis and surface presentation of IL- 8 by venular endothelial cells. Cell 1997;91:385-395.

19 McCaughan GW, Gorrell MD, Bishop GA, et al: Molecular pathogenesis of liver disease: an approach to hepatic inflammation, cirrhosis and liver transplant tolerance. Immunol Rev 2000;174:172-191.

20 Nibbs R, Graham G, Rot A: Chemokines on the move: control by the chemokine 'interceptors' Duffy blood group antigen and D6. Semin Immunol 2003;15:287-294. 
21 Colditz IG, Schneider MA, Pruenster M, Rot A: Chemokines at large: in-vivo mechanisms of their transport, presentation and clearance. Thromb Haemost 2007;97:688-693.

22 Crispe IN: The liver as a lymphoid organ. Annu Rev Immunol 2009;27:147-163.

$\checkmark 23$ Knolle PA, Gerken G: Local control of the immune response in the liver. Immunol Rev 2000;174:21-34.

-24 Eksteen B, Afford SC, Wigmore SJ, Holt AP, Adams DH: Immune-mediated liver injury. Semin Liver Dis 2007;27:351-366.

25 Cua DJ, Sherlock J, Chen Y, et al: Interleukin-23 rather than interleukin-12 is the critical cytokine for autoimmune inflammation of the brain. Nature 2003;421:744-748.

26 Stockinger B, Veldhoen M, Martin B: Th17 T cells: linking innate and adaptive immunity. Semin Immunol 2007;19:353-361.

-27 Bettelli E, Carrier Y, Gao W, et al: Reciprocal developmental pathways for the generation of pathogenic effector TH17 and regulatory T cells. Nature 2006;441:235-238.

28 O'Garra A, Stockinger B, Veldhoen M: Differentiation of human $\mathrm{T}(\mathrm{H})-17$ cells does require TGF-beta! Nat Immunol 2008;9:588590.

29 Harrington LE, Mangan PR, Weaver CT: Expanding the effector $\mathrm{CD} 4 \mathrm{~T}$-cell repertoire: the Th17 lineage. Curr Opin Immunol 2006; 18:349-356

-30 Langrish CL, Chen Y, Blumenschein WM, et al: IL-23 drives a pathogenic T cell population that induces autoimmune inflammation. J Exp Med 2005;201:233-240.

- 31 Annunziato F, Cosmi L, Santarlasci V, et al: Phenotypic and functional features of human Th17 cells. J Exp Med 2007;204:18491861.

-32 Lan RY, Salunga TL, Tsuneyama K, et al: Hepatic IL-17 responses in human and murine primary biliary cirrhosis. J Autoimmun 2009;32:43-51.

33 Lemmers A, Moreno C, Gustot T, et al: The interleukin-17 pathway is involved in human alcoholic liver disease. Hepatology 2009;49: 646-657.

34 Yasumi Y, Takikawa Y, Endo R, Suzuki K: Interleukin-17 as a new marker of severity of acute hepatic injury. Hepatol Res 2007;37: 248-254.

- 35 Zenewicz LA, Yancopoulos GD, Valenzuela DM, Murphy AJ, Karow M, Flavell RA: Interleukin-22 but not interleukin-17 provides protection to hepatocytes during acute liver inflammation. Immunity 2007;27:647-659.

-36 Zhang JY, Zhang Z, Lin F, et al: Interleukin17-producing CD4(+) T cells increase with severity of liver damage in patients with chronic hepatitis B. Hepatology 2010;51:8191.

- 37 Brand S, Dambacher J, Beigel F, et al: IL-22mediated liver cell regeneration is abrogated by SOCS-1/3 overexpression in vitro. Am J Physiol Gastrointest Liver Physiol 2007; 292:G1019-G1028.
38 Kimura A, Naka T, Nohara K, Fujii-Kuriyama Y, Kishimoto T: Aryl hydrocarbon receptor regulates Stat 1 activation and participates in the development of Th17 cells. Proc Natl Acad Sci USA 2008;105:9721-9726.

39 Veldhoen M, Hirota K, Christensen J, O'Garra A, Stockinger B: Natural agonists for aryl hydrocarbon receptor in culture medium are essential for optimal differentiation of Th17 T cells. J Exp Med 2009;206: 43-49.

40 Nguyen LP, Bradfield CA: The search for endogenous activators of the aryl hydrocarbon receptor. Chem Res Toxicol 2008;21:102116.

41 Northfield JW, Kasprowicz V, Lucas M, Klenerman $\mathrm{P}$, et al: CD161 expression on hepatitis $C$ virus-specific $C D 8+T$ cells suggests a distinct pathway of $\mathrm{T}$ cell differentiation. Hepatology 2008;47:396-406.

42 Annunziato F, Cosmi L, Liotta F, Maggi E, Romagnani S: The phenotype of human Th17 cells and their precursors, the cytokines that mediate their differentiation and the role of Th17 cells in inflammation. Int Immunol 2008;20:1361-1368.

43 Hirota K, Yoshitomi H, Hashimoto M, et al: Preferential recruitment of CCR6-expressing Th17 cells to inflamed joints via CCL20 in rheumatoid arthritis and its animal model. J Exp Med 2007;204:2803-2812.

44 Singh SP, Zhang HH, Foley JF, Hedrick MN, Farber JM: Human $\mathrm{T}$ cells that are able to produce IL-17 express the chemokine receptor CCR6. J Immunol 2008;180:214-221.

45 Nistala K, Moncrieffe $H$, Newton KR, Varsani H, Hunter P, Wedderburn LR: Interleukin-17-producing $\mathrm{T}$ cells are enriched in the joints of children with arthritis, but have a reciprocal relationship to regulatory $\mathrm{T}$ cell numbers. Arthritis Rheum 2008;58:875887.

46 Adams DH, Eksteen B: Aberrant homing of mucosal $\mathrm{T}$ cells and extra-intestinal manifestations of inflammatory bowel disease. Nat Rev Immunol 2006;6:244-251.

47 Eksteen B, Miles AE, Grant AJ, Adams DH: Lymphocyte homing in the pathogenesis of extra-intestinal manifestations of inflammatory bowel disease. Clin Med 2004;4:173180.

48 Lalor PF, Adams DH: Adhesion of lymphocytes to hepatic endothelium. Mol Pathol 1999;52:214-219.

49 Valiante NM, D’Andrea A, Crotta S, et al: Life, activation and death of intrahepatic lymphocytes in chronic hepatitis C. Immunol Rev 2000;174:77-89.

50 Napoli J, Bishop GA, McGuinness PH, Painter DM, McCaughan GW: Progressive liver injury in chronic hepatitis $\mathrm{C}$ infection correlates with increased intrahepatic expression of Th1-associated cytokines. Hepatology 1996;24:759-765.
51 Shields PL, Morland CM, Salmon M, Qin S, Hubscher SG, Adams DH: Chemokine and chemokine receptor interactions provide a mechanism for selective $\mathrm{T}$ cell recruitment to specific liver compartments within hepatitis C-infected liver. J Immunol 1999;163: 6236-6243.

52 Bertoletti A, D’Elios MM, Boni C, et al: Different cytokine profiles of intraphepatic $\mathrm{T}$ cells in chronic hepatitis B and hepatitis C virus infections. Gastroenterology 1997;112: 193-199, comment by Woitas KR, Sauerbruch T, Spengler H in Gastroenterology 1997;113:1050-1051.

- 53 Kunkel EJ, Boisvert J, Murphy K, et al: Expression of the chemokine receptors CCR4, CCR5, and CXCR3 by human tissue-infiltrating lymphocytes. Am J Pathol 2002;160: 347-355.

- 54 Heydtmann M, Hardie D, Shields PL, et al: Detailed analysis of intrahepatic CD8 T cells in the normal and hepatitis C-infected liver reveals differences in specific populations of memory cells with distinct homing phenotypes. J Immunol 2006;177:729-738.

-55 Boisvert J, Kunkel EJ, Campbell JJ, Keeffe EB, Butcher EC, Greenberg HB: Liver-infiltrating lymphocytes in end-stage hepatitis $C$ virus: subsets, activation status, and chemokine receptor phenotypes. J Hepatol 2003;38: 67-75.

56 Leroy V, Vigan I, Mosnier JF, et al: Phenotypic and functional characterization of intrahepatic $\mathrm{T}$ lymphocytes during chronic hepatitis C. Hepatology 2003;38:829-841.

57 Murai M, Yoneyama H, Harada A, et al: Active participation of CCR5(+)CD8(+) T lymphocytes in the pathogenesis of liver injury in graft-versus-host disease. J Clin Invest 1999;104:49-57.

58 Ajuebor MN, Hogaboam CM, Le T, Proudfoot AE, Swain MG: CCL3/MIP-1alpha is pro-inflammatory in murine $\mathrm{T}$ cell-mediated hepatitis by recruiting CCR1-expressing CD4(+) T cells to the liver. Eur J Immunol 2004;34:2907-2918.

59 Harvey CE, Post JJ, Palladinetti P, et al: Expression of the chemokine IP-10 (CXCL10) by hepatocytes in chronic hepatitis $C$ virus infection correlates with histological severity and lobular inflammation. J Leukoc Biol 2003; 74:360-369.

60 Curbishley SM, Eksteen B, Gladue RP, Lalor P, Adams DH: CXCR3 activation promotes lymphocyte transendothelial migration across human hepatic endothelium under fluid flow. Am J Pathol 2005;167:887-899.

61 Arai K, Liu ZX, Lane T, Dennert G: IP-10 and Mig facilitate accumulation of $\mathrm{T}$ cells in the virus-infected liver. Cell Immunol 2002;219: 48-56.

62 Dumoulin FL, Bach A, Leifeld L, et al: Semiquantitative analysis of intrahepatic cytokines mRNA in chronic hepatitis C. J Infect Dis 1997;175:681-685. 
63 Diago M, Castellano G, Garcia-Samaniego J, et al: Association of pretreatment serum interferon gamma inducible protein 10 levels with sustained virological response to peginterferon plus ribavirin therapy in genotype 1 infected patients with chronic hepatitis C. Gut 2006;55:374-379.

-64 Apolinario A, Majano PL, Alvarez-Perez E, et al: Increased expression of $\mathrm{T}$ cell chemokines and their receptors in chronic hepatitis C: relationship with the histological activity of liver disease. Am J Gastroenterol 2002;97: 2861-2870.

-65 Larrubia JR, Calvino M, Benito S, et al: The role of CCR5/CXCR3 expressing CD8+ cells in liver damage and viral control during persistent hepatitis $\mathrm{C}$ virus infection. J Hepatol 2007:47:632-641.

- 66 Butera D, Marukian S, Iwamaye AE, et al: Plasma chemokine levels correlate with the outcome of antiviral therapy in patients with hepatitis C. Blood 2005;106:1175-1182.

-67 Nishioji K, Okanoue T, Itoh Y, et al: Increase of chemokine interferon-inducible protein-10 (IP-10) in the serum of patients with autoimmune liver diseases and increase of its mRNA expression in hepatocytes. Clin Exp Immunol 2001;123:271-279.

-68 Helbig KJ, Ruszkiewicz A, Semendric L, Harley HA, McColl SR, Beard MR: Expression of the CXCR3 ligand I-TAC by hepatocytes in chronic hepatitis $\mathrm{C}$ and its correlation with hepatic inflammation. Hepatology 2004;39: 1220-1229.

-69 Cruise MW, Lukens JR, Nguyen AP, Lassen MG, Waggoner SN, Hahn YS: Fas ligand is responsible for CXCR3 chemokine induction in $\mathrm{CD} 4+\mathrm{T}$ cell-dependent liver damage. J Immunol 2006;176:6235-6244.

-70 Eksteen B, Grant AJ, Miles A, et al: Hepatic endothelial CCL25 mediates the recruitment of CCR9+ gut-homing lymphocytes to the liver in primary sclerosing cholangitis. J Exp Med 2004;200:1511-1517.

-71 Middleton J, Patterson AM, Gardner L, Schmutz C, Ashton BA: Leukocyte extravasation: chemokine transport and presentation by the endothelium. Blood 2002;100: 3853-3860.

72 Shiratori Y, Takada H, Hikiba Y, et al: Production of chemotactic factor, interleukin-8, from hepatocytes exposed to ethanol. Hepatology 1993; 18:1477-1482.

73 Morland CM, Fear J, McNab G, Joplin R, Adams DH: Promotion of leukocyte transendothelial cell migration by chemokines derived from human biliary epithelial cells in vitro. Proc Assoc Am Physicians 1997;109:372382.

74 Maher JJ: Rat hepatocytes and Kupffer cells interact to produce interleukin-8 (CINC) in the setting of ethanol. Am J Physiol 1995; 269:G518-G523.

-75 Edwards S, Lalor PF, Nash GB, Rainger GE, Adams DH: Lymphocyte traffic through sinusoidal endothelial cells is regulated by hepatocytes. Hepatology 2005;41:451-459.
Alabraba EB, Lai V, Boon L, Wigmore SJ, Adams DH, Afford SC: Coculture of human liver macrophages and cholangiocytes leads to CD40-dependent apoptosis and cytokine secretion. Hepatology 2008;47:552-562.

-77 Ahmed-Choudhury J, Russell CL, Randhawa $S$, et al: Differential induction of nuclear factor-kappaB and activator protein-1 activity after CD40 ligation is associated with primary human hepatocyte apoptosis or intrahepatic endothelial cell proliferation. Mol Biol Cell 2003;14:1334-1345.

78 Eksteen B, Miles A, Curbishley SM, et al: Epithelial inflammation is associated with CCL28 production and the recruitment of regulatory $\mathrm{T}$ cells expressing CCR10. J Immunol 2006; 177:593-603.

79 Matloubian M, David A, Engel S, Ryan JE, Cyster JG: A transmembrane CXC chemokine is a ligand for HIV-coreceptor Bonzo. Nat Immunol 2000;1:298-304.

80 Wilbanks A, Zondlo SC, Murphy K, et al: Expression cloning of the STRL33/BONZO/ TYMS TRligand reveals elements of CC $\mathrm{CXC}$, and $\mathrm{CX} 3 \mathrm{C}$ chemokines. J Immunol 2001;166:5145-5154.

81 Heydtmann M, Lalor PF, Eksteen JA, Hubscher SG, Briskin M, Adams DH: CXC chemokine ligand 16 promotes integrin-mediated adhesion of liver-infiltrating lymphocytes to cholangiocytes and hepatocytes within the inflamed human liver. J Immunol 2005; 174:1055-1062.

82 Germanov E, Veinotte L, Cullen R, Chamberlain E, Butcher EC, Johnston B: Critical role for the chemokine receptor CXCR6 in homeostasis and activation of CD1d-restricted NKT cells. J Immunol 2008;181:8191.

83 Wald O, Pappo O, Safadi R, et al: Involvement of the CXCL12/CXCR4 pathway in the advanced liver disease that is associated with hepatitis C virus or hepatitis B virus. Eur J Immunol 2004;34:1164-1174.

84 Terada R, Yamamoto K, Hakoda T, et al: Stromal cell-derived factor-1 from biliary epithelial cells recruits CXCR4-positive cells: implications for inflammatory liver diseases. Lab Invest 2003;83:665-672.

- 85 Efsen E, Grappone C, Defranco RM, et al: Up-regulated expression of fractalkine and its receptor CX3CR1 during liver injury in humans. J Hepatol 2002;37:39-47.

86 Isse K, Harada K, Zen Y, et al: Fractalkine and CX3CR1 are involved in the recruitment of intraepithelial lymphocytes of intrahepatic bile ducts. Hepatology 2005;41:506-516.

88 Kunkel EJ, Campbell DJ, Butcher EC: Chemokines in lymphocyte trafficking and intestinal immunity. Microcirculation 2003; 10:313-323.

88 Pan J, Kunkel EJ, Gosslar U, et al: A novel chemokine ligand for CCR10 and CCR3 expressed by epithelial cells in mucosal tissues. J Immunol 2000;165:2943-2949.
89 Viola A, Luster AD: Chemokines and their receptors: drug targets in immunity and inflammation. Annu Rev Pharmacol Toxicol 2008:48:171-197.

\$0 Lichterfeld M, Leifeld L, Nischalke HD, et al: Reduced CC chemokine receptor (CCR) 1 and CCR5 surface expression on peripheral blood $\mathrm{T}$ lymphocytes from patients with chronic hepatitis $\mathrm{C}$ infection. J Infect Dis 2002; 185:1803-1807.

-91 Nattermann J, Sherzada R, Iwan A, et al: Hepatitis $\mathrm{C}$ virus-induced secretion of inflammatory chemokines preferentially recruits NKG2A(+)CD8(+) T cells. J Infect Dis 2008; 198:213-217.

92 Nischalke HD, Nattermann J, Fischer HP, Sauerbruch T, Spengler U, Dumoulin FL: Semiquantitative analysis of intrahepatic CC-chemokine mRNas in chronic hepatitis C. Mediators Inflamm 2004;13:357359.

93 Qin S, Rottman JB, Myers P, et al: The chemokine receptors CXCR3 and CCR5 mark subsets of T cells associated with certain inflammatory reactions. J Clin Invest 1998; 101:746-754.

94 Goddard S, Williams A, Morland C, et al: Differential expression of chemokines and chemokine receptors shapes the inflammatory response in rejecting human liver transplants. Transplantation 2001;72:19571967.

$\checkmark 95$ Murai M, Yoneyama H, Ezaki T, et al: Peyer's patch is the essential site in initiating murine acute and lethal graft-versus-host reaction. Nat Immunol 2003;4:154-160.

$\$ 96$ Moreno C, Gustot T, Nicaise C, et al: CCR5 deficiency exacerbates T-cell-mediated hepatitis in mice. Hepatology 2005;42:854862.

\$9 Ajuebor MN, Aspinall AI, Zhou F, et al: Lack of chemokine receptor CCR5 promotes murine fulminant liver failure by preventing the apoptosis of activated CD1drestricted NKT cells. J Immunol 2005; 174: 8027-8037.

$\checkmark 98$ Grant AJ, Goddard S, Ahmed-Choudhury $\mathrm{J}$, et al: Hepatic expression of secondary lymphoid chemokine (CCL21) promotes the development of portal-associated lymphoid tissue in chronic inflammatory liver disease. Am J Pathol 2002;160:14451455.

99 Hjelmstrom P, Fjell J, Nakagawa T, Sacca R, Cuff CA, Ruddle NH: Lymphoid tissue homing chemokines are expressed in chronic inflammation. Am J Pathol 2000; 156:1133-1138.

100 Bonacchi A, Petrai I, Defranco RM, et al: The chemokine CCL21 modulates lymphocyte recruitment and fibrosis in chronic hepatitis C. Gastroenterology 2003;125: 1060-1076.

101 Mondelli MU: Multifaceted functions of B cells in chronic hepatitis $\mathrm{C}$ virus infection. Antiviral Res 2003;60:111-115. 
102 Faint JM, Annels NE, Curnow SJ, et al: Memory $\mathrm{T}$ cells constitute a subset of the human CD8+CD45RA+ pool with distinct phenotypic and migratory characteristics. J Immunol 2001;167:212-220.

103 Förster R, Davalos-Misslitz AC, Rot A: CCR7 and its ligands: balancing immunity and tolerance. Nat Rev Immunol 2008;8: 362-371.

-104 Schneider MA, Meingassner JG, Lipp M, Moore HD, Rot A: CCR7 is required for the in vivo function of CD4+ CD25+ regulatory T cells. J Exp Med 2007;204:735-745.

105 Bromley SK, Thomas SY, Luster AD: Chemokine receptor CCR7 guides $\mathrm{T}$ cell exit from peripheral tissues and entry into afferent lymphatics. Nat Immunol 2005;6: 895-901.

106 Briskin M, Winsor-Hines D, Shyjan A, et al: Human mucosal addressin cell adhesion molecule-1 is preferentially expressed in intestinal tract and associated lymphoid tissue. Am J Pathol 1997;151:97-110.

- 107 Hillan KJ, Hagler KE, MacSween RN, et al: Expression of the mucosal vascular addressin, MAdCAM-1, in inflammatory liver disease. Liver 1999;19:509-518.

-108 Grant AJ, Lalor PF, Hubscher SG, Briskin M, Adams DH: MAdCAM-1 expressed in chronic inflammatory liver disease supports mucosal lymphocyte adhesion to hepatic endothelium (MAdCAM-1 in chronic inflammatory liver disease). Hepatology 2001;33:1065-1072.

109 Agace WW: Tissue-tropic effector T cells: generation and targeting opportunities. Nat Rev Immunol 2006;6:682-692.

$\checkmark 110$ Mora JR, Iwata M, Eksteen B, et al: Generation of gut-homing IgA-secreting B cells by intestinal dendritic cells. Science 2006;314: 1157-1160.

-111 Eksteen B, Mora JR, Haughton EL, et al: Gut homing receptors on CD8 T-cells are retinoic acid dependent and not maintained by liver dendritic or stellate cells. Gastroenterology 2009;137:320-329.
112 Lee JH, Kang SG, Kim CH: FoxP3+ T cells undergo conventional first switch to lymphoid tissue homing receptors in thymus but accelerated second switch to nonlymphoid tissue homing receptors in secondary lymphoid tissues. J Immunol 2007;178:301311.

113 Cyster JG: Chemokines, sphingosine-1phosphate, and cell migration in secondary lymphoid organs. Annu Rev Immunol 2005;23:127-159.

114 Miyasaka M, Tanaka T: Lymphocyte trafficking across high endothelial venules: dogmas and enigmas. Nat Rev Immunol 2004;4:360-370.

115 von Andrian UH, Mempel TR: Homing and cellular traffic in lymph nodes. Nat Rev Immunol 2003;3:867-878

116 Mantovani A, Sica A, Sozzani S, Allavena P, Vecchi A, Locati M: The chemokine system in diverse forms of macrophage activation and polarization. Trends Immunol 2004; 25:677-686.

117 Adams DH, Harvath L, Bottaro DP, et al: Hepatocyte growth factor and macrophage inflammatory protein 1 beta: structurally distinct cytokines that induce rapid cytoskeletal changes and subset-preferential migration in T cells. Proc Natl Acad Sci USA 1994;91:7144-7148.

118 Hathaway M, Burnett D, Elias E, Adams DH: Secretion of soluble chemotactic factors, including interleukin-6: a mechanism for the recruitment of CD8-positive T lymphocytes to human liver allografts during rejection. Hepatology 1993;18:511-518.

119 Holt AP, Haughton EL, Lalor PF, Filer A, Buckley CD, Adams DH: Liver myofibroblasts regulate infiltration and positioning of lymphocytes in human liver. Gastroenterology 2009;136:705-714.

120 Heydtmann M, Adams DH: Chemokines in the immunopathogenesis of hepatitis $\mathrm{C}$ infection. Hepatology 2009;49:676-688.

-121 Benseler V, McCaughan GW, Schlitt HJ, Bishop GA, Bowen DG, Bertolino P: The liver: a special case in transplantation tolerance. Semin Liver Dis 2007;27:194-213.
122 Bowen DG, McCaughan GW, Bertolino P: Intrahepatic immunity: a tale of two sites? Trends Immunol 2005;26:512-517.

123 Bowen DG, Zen M, Holz L, Davis T, McCaughan GW, Bertolino P: The site of primary $\mathrm{T}$ cell activation is a determinant of the balance between intrahepatic tolerance and immunity. J Clin Invest 2004;114:701712 .

124 Chen W, Jin W, Hardegen N, et al: Conversion of peripheral CD4+CD25- naive $\mathrm{T}$ cells to $\mathrm{CD} 4+\mathrm{CD} 25+$ regulatory $\mathrm{T}$ cells by TGF-beta induction of transcription factor Foxp3. J Exp Med 2003;198:1875-1886.

125 Veldhoen M, Stockinger B: TGFbeta1, a 'Jack of all trades': the link with pro-inflammatory IL-17-producing T cells. Trends Immunol 2006;27:358-361.

126 Veldhoen M, Hocking RJ, Atkins CJ, Locksley RM, Stockinger B: TGFbeta in the context of an inflammatory cytokine milieu supports de novo differentiation of IL-17-producing T cells. Immunity 2006; 24:179-189.

127 Wilson NJ, Boniface K, Chan JR, et al: Development, cytokine profile and function of human interleukin 17-producing helper $\mathrm{T}$ cells. Nat Immunol 2007;8:950-957.

128 Costa-Rodriguez EV, Napolitani G, Lanzavecchia A, Sallusto F: Interleukins 1beta and 6 but not transforming growth factorbeta are essential for the differentiation of interleukin 17-producing human $\mathrm{T}$ helper cells. Nat Immunol 2007;8:942-949.

129 Billerbeck E, Kang YH, Walker L, et al: Analysis of CD161 expression on human CD8+ T cells defines a distinct functional subset with tissue-homing properties. Proc Natl Acad Sci USA 2010;107:3006-3011.

130 Oo YH, Weston CJ, Lalor PF, et al: Distinct roles of CCR4 and CXCR3 in the recruitment and positioning of regulatory $\mathrm{T}$ cells in the inflamed human liver. J Immunol 2010;184:2886-2898. 